JOURNAL OF TECHNOLOGY AND

OPERATIONS MANAGEMENT

http://e-journal.uum.edu.my/index.php/jtom

How to cite this article:

Suhardi, B., Addina, D. A., \& Astuti, R. D. (2020). Improvement of Work Temperature At Content Printing Workstation In Publishers And Printing CV Grafika Dua Tujuh. Journal of Technology and Operations Management, 15(2), 52-62. https://doi.org/10.32890/jtom2020.15.2.6

\title{
IMPROVEMENT OF WORK TEMPERATURE AT CONTENT PRINTING WORKSTATION IN PUBLISHERS AND PRINTING CV GRAFIKA DUA TUJUH
}

\author{
${ }^{1}$ Bambang Suhardi, ${ }^{3}$ Dwinda Asyfi Addina $\&{ }^{3}$ Rahmaniyah Dwi Astuti \\ ${ }^{1,3}$ Industrial Engineering Lecturers, Engineering Faculty, Sebelas Maret University \\ ${ }^{2}$ Industrial Engineering Alumni, Engineering Faculty, Sebelas Maret University \\ Corresponding addresses: $\underline{\text { bambangsuhardi@ staff.uns.ac.id }}$
}

Received: 07/8/2020 Revised: 02/9/2020 Accepted: 24/11/2020 Published: 29/12/2020

\begin{abstract}
CV. Grafika Dua Tujuh is an industry engaged in publishing and printing books and student worksheets located in Klaten. The average output produced daily is 85.400 books and student worksheets, while the company has a production target of 90.000 books and student worksheets. Based on the results of interviews with workers, the level of production that is not maximal is caused by an uncomfortable working environment. Workers in the production room complained about the condition of a hot work environment so that workers feel easily tired and lack of concentration. To overcome the hot workplace, workers often go to the restroom and they work while holding the hand fan. This condition disturbed their concentration and cause work errors. If this condition is carried out continuously, there will be a lot of lost work time which can cause a decrease in productivity. This study aims to analyze the improvement of working temperature conditions in the production room of CV. Grafika Dua Tujuh. This research was conducted by directly measuring thermal conditions in the entire production room of CV. Grafika Dua Tujuh. Determination of the coordinate point of room temperature measurement is based on SNI: 16-7061-2004. Workload assessment is carried out based on SNI 7269: 2009. The results of the measurement of work climate at the content printing workstation are the values of air temperature, humidity, and wind speed i.e $33.32{ }^{\circ} \mathrm{C}, 39.9 \%$, and $0 \mathrm{~m} / \mathrm{s}$. In addition, Wet Bulb Globe Temperature Index (WBGT) value is obtained which is on the verge of a limit, i.e $29.90{ }^{\circ} \mathrm{C}$ for the category of the heavy workload with an allocation of working time of $87.5 \%$. The temperature is above the standard set by the Ministry of Health of the Republic of Indonesia No. 1405 / MENKES / 2002 which sets the temperature in an industrial room ranging from $18{ }^{\circ} \mathrm{C}-28{ }^{\circ} \mathrm{C}$. Improvement for working temperature is done by engineering control, namely the installation of a turbine ventilator or exhaust fan.
\end{abstract}

Keywords: Working temperature, workload, engineering control 


\section{INTRODUCTION}

The physical work environment affects employee morale and emotions, which consists of: lighting, noise, air temperature, room color, and workplace cleanliness (Senata et al, 2014). The work climate is a combination of air temperature, air humidity, air velocity, and radiation heat with the level of heat dissipation from the body of the workforce as a result of their work (Ministry of Manpower and Transmigration, 2011). There is a relationship between air temperature and the work productivity of workers, if the air temperature increases, the work productivity will decrease (Mamahit, Kawatu, \& Molanda, 2016). A comfortable working environment will have an impact on the mental health of the workers (Munandar, 2001). A standard is needed to assess the workload that can be calculated based on the level of calorie needs according to energy expenditure on labor (National Standardization Agency of Indonesia, 2009).

CV. Grafika Dua Tujuh is a book printing industry and student worksheets printing located at Jl. Diponegoro, Karanganom, Klaten. The factory has an area of 7,205 $\mathrm{m} 2$ which is located in a residential area. CV. Grafika Dua Tujuh has 112 workers. The average output produced each day is 85,400 books and worksheets, while the company has a production target of 90,000 books and worksheets. Based on the results of interviews with workers, the level of production that is not optimal is triggered by an uncomfortable working environment.

Workers or people who feel uncomfortable at work will lose motivation and take more time off (Wyon \& Wargocki, 2005). This can be seen from the way workers at CV. Grafika Dua Tujuh relieves heat. They frequently going to the bathroom and working while holding a hand fan, so that their concentration is distracted and causes work errors. If this condition occurs continuously, there will be a lot of lost work time that can reduce productivity. The results of the preliminary study of measuring the working climate at one of the production room workstations are the air temperature value of $33.32{ }^{\circ} \mathrm{C}$, air humidity of $39.9 \%$, and wind speed of $0 \mathrm{~m} / \mathrm{s}$. This is not following the Indonesian Ministry of Health Number 1405 / MENKES / 2002, which stipulates that the air temperature in industrial rooms ranges from $18{ }^{\circ} \mathrm{C}-28{ }^{\circ} \mathrm{C}$, humidity $40 \%-60 \%$, and wind speed $0.15 \mathrm{~m} / \mathrm{s}-0,25 \mathrm{~m} / \mathrm{s}$ (Ministry of Health, 2002).

Research related to the work climate has been done before. One of the studies was conducted in the cracker industry in the frying and steaming section to find out whether the work climate is following the threshold value set by the Ministry of Manpower and Transmigration of The Republic of Indonesia, namely by using the WBGT parameter (Meri \& Putra, 2016). One of the designs to improve the work climate is carried out by using a turbine ventilator so that it can reduce the air temperature by $2 \%$ and increase wind speed by $0.2 \mathrm{~m} / \mathrm{s}$ (Pandiangan, Huda, \& Rambe, 2013). Based on computational fluid dynamics (CFD) simulations, it is known that the use of a rooftop turbine ventilator can make air quality better and increase comfort with the exhaust rate by the turbine ventilator (Lien \& Ahmed, 2002).

There are several previous studies related to turbine ventilators as a design improvement for temperature conditions in the workplace. Several studies have carried out engineering control using turbine ventilators to improve the thermal comfort of workers in mosquito repellent manufacturing plants (Huda \& Pandiangan, 2012; Pandiangan, Huda, \& Rambe, 2013). The use of turbine ventilators is also proposed to improve air circulation at the garment company workstations, which are still not in ergonomic conditions (Rasyid, Surachman, \& Sugiono, 2016). The use of Hybrid Turbine Ventilators (HTV) to increase the stack effect in buildings in Malaysia that has a hot and humid climate has also been done before (Rifa, Al-Obaidi, \& Rahman, 2014). A study also tried to determine the effect of the number and angle of vertical blades on the cyclone turbine ventilator on the thermal comfort of the room (Karim, Qiram, \& Sartika, 2018). In addition to the use of a turbine ventilator, an automatic system has also been developed to control the temperature and humidity of the fruit storage room automatically so that it can delay the fruit-ripening rate for 21 days (Amin \& Adha, 2017). 
Based on this description, it is necessary to analyze and improve the working temperature in the production room of CV. Grafika Dua Tujuh. One of the improvements in working temperature is engineering control, namely the installation of a turbine ventilator or exhaust fan.

\section{RESEARCH METHOD}

\section{Working Temperature Assessment Procedure}

This research was conducted in the production room of CV. Grafika Dua Tujuh. Data observed and retrieved based on the thermal conditions in the room. Thermal measurements were performed using a 4 in 1 envirometer, anemometer, and area heat stress monitor. The 4 in 1 envirometer is used to measure air temperature and humidity. Anemometer is used to measure wind speed. The area heat stress monitor is used to measure the WBGT. Based on SNI-16-7061-2004 measurements are made according to the area of the room then the coordinate grid of measurements is determined, and based on ASHRAE, measurements are made with gradient levels, namely $0.1 \mathrm{~m}, 1.1 \mathrm{~m}$, and $1.7 \mathrm{~m}$. Measurements were taken for 3 working days from 09.00 to 16.00 WIB with 1-hour intervals.

\section{Workload Assessment Procedure}

Assessment of workforce activity at each workstation is calculated based on the level of calorie energy demand according to SNI 7269: 2009 so that the level of workload experienced by workers in the production room of CV Grafika Dua Tujuh can be obtained. Assessment of workload based on the level of calorie needs according to energy expenditure according to SNI 7269: 2009 as shown in Table 1.

Table 1.

Workload Assessment

\begin{tabular}{ccc}
\hline No & Kind of Work & $\begin{array}{c}\text { Calories Expended } \\
(\mathrm{kcal} / \mathrm{hours})\end{array}$ \\
\hline 1 & Light & $100-200$ \\
2 & Moderate & $>200-350$ \\
3 & Weight & $>350-500$ \\
\hline
\end{tabular}

The results of the work climate measurement are then compared with the results of the workload assessment following Permenaker No. 13 of 2011 regarding the WBGT standard value. The permissible WBGT index threshold values are shown in Table 2.

Table 2.

WBGT Index Threshold Values

\begin{tabular}{lccc}
\hline Hourly Working Time Setting & \multicolumn{3}{c}{$\begin{array}{c}\text { WBGT } \\
\left({ }^{0} \mathrm{C}\right) \\
\text { Workload }\end{array}$} \\
\cline { 2 - 4 } $75 \%-100 \%$ & Light & Moderate & Weight \\
\cline { 2 - 4 } $50 \%-75 \%$ & 31,0 & 28,0 & \\
$25 \%-50 \%$ & 31,0 & 29,0 & 27,5 \\
$0 \%-25 \%$ & 32,0 & 30,0 & 29,0 \\
\hline
\end{tabular}




\section{Working Temperature Improvement Procedure}

Heat exposure is handled by engineering controls so that it can increase the thermal comfort of workers. The steps taken were started from determining the criteria for the room and how to improve thermal comfort according to the criteria. Then an analysis of the optimal amount and the placement of the thermal comfort improvement facility was carried out. The next step is to analyze the feasibility of investing in additional facilities at CV. Grafika Dua Tujuh.

\section{RESULTS AND DISCUSSION}

\section{Air Temperature}

Average temperature conditions in the production room of CV. Grafika Dua Tujuh can be categorized as high. The average temperature at setting station is $32.67^{\circ} \mathrm{C}$, editor station is $32.83^{\circ} \mathrm{C}$, CTP station is $29.67^{\circ} \mathrm{C}$, content printing station is $33.32^{\circ} \mathrm{C}$, cover printing station is $33.25^{\circ} \mathrm{C}$, key printing station is $33.24^{\circ} \mathrm{C}$, UV varnish station is $33.04^{\circ} \mathrm{C}$, binding station is $34.28^{\circ} \mathrm{C}$, stitching station is $133.80^{\circ}$ $\mathrm{C}$, and mixed station is $32.83^{\circ} \mathrm{C}$. The average temperature value at the ten work stations is above the threshold limit value (TLV) according to the Indonesian Ministry of Health Number 1405 / MENKES / SK / XI / 2002 where the specified temperature is $18-28^{\circ} \mathrm{C}$. The high-temperature value is influenced by the lack of air circulation in the room because the production room has only small ventilation. In addition, the roof is made of zinc so that it is exposed to high heat exposure because zinc is a medium for conducting heat or usually called as a conductor.

\section{Wet-Bulb Temperature, Dry-Bulb Temperature, Globe Thermometer Temperature, and WBGT}

WBGT measurements are carried out at a height of 1.1 meters from the ground floor of the room using the Heat Stress Area which can directly measure the value of the four measurement quantities. The position of the instrument when measuring is in the middle of the measured production room.

The results of measurements of wet-bulb temperature, dry-bulb temperature, globe thermometer temperature, and WBGT in the production room of CV. Grafika Dua Tujuh is in Table 3 below.

Table 3.

Wet-Bulb Temperature Dry-Bulb Temperature, Globe Thermometer Temperature, and Measurement WBGT.

\begin{tabular}{cccccc}
\hline No & Workstation & $\begin{array}{c}\text { Wet-Bulb } \\
\text { Temperature } \\
\left({ }^{\circ} \mathrm{C}\right)\end{array}$ & $\begin{array}{c}\text { Dry-Bulb } \\
\text { Temperature } \\
\left({ }^{\circ} \mathrm{C}\right)\end{array}$ & $\begin{array}{c}\text { Globe } \\
\text { Thermometer } \\
\text { Temperature } \\
\left({ }^{\circ} \mathrm{C}\right)\end{array}$ & $\begin{array}{c}\text { WBGT } \\
\left({ }^{\circ} \mathrm{C}\right)\end{array}$ \\
\hline 1 & Setting & 21,5 & 30,3 & 30,8 & 24,3 \\
2 & Editor & 24,2 & 31,4 & 32,6 & 26,7 \\
3 & Computer to Plate & 20,3 & 24,8 & 28,0 & 22,6 \\
4 & Content printing & 27,8 & 34,6 & 34,8 & 29,9 \\
5 & Cover printing & 24,4 & 31,0 & 33,1 & 27,0 \\
6 & Key printing & 27,3 & 33,9 & 34,4 & 29,4 \\
7 & UV varnish & 27,3 & 32,7 & 33,7 & 29,2 \\
8 & Binding & 27,8 & 34,6 & 35,4 & 30,1 \\
9 & Stitching & 27,3 & 34,0 & 34,3 & 29,4 \\
10 & Packing, Cutting, & 27 & 32,8 & 34,0 & 29,1 \\
\hline
\end{tabular}

The WBGT that has been obtained from the measurement results using the Area Heat Stress Monitor will be compared with the WBGT value calculated manually. The following is the WBGT calculation 
in the production room of CV. Grafika Dua Tujuh. The WBGT calculation is as follows:

$\mathrm{WBGT}=0,7_{T w}+0,3_{T g}$

Where,

${ }_{\mathrm{Tw}}=$ Natural Wet-Bulb Temperature $\left({ }^{\circ} \mathrm{C}\right)$

$\mathrm{Tg}=$ Globe Thermometer Temperature $\left({ }^{\circ} \mathrm{C}\right)$

WBGT for Content Printing Workstation $=0,7_{T w}+0,3_{\mathrm{Tg}}$

WBGT for Content Printing Workstation $=0,7 \times 27,8+0,3 \times 34,8$

WBGT for Content Printing Workstation $=19,46+10,44=29,9^{\circ} \mathrm{C}$

The WBGT measurement results are then compared with the WBGT calculation in Table 4.

\section{Table 4.}

Comparison between The Value of Measurement WBGT and Calculation WBGT.

\begin{tabular}{ccccc}
\hline No & Workstation & $\begin{array}{c}\text { Measurement } \\
\text { WBGT }\left({ }^{\circ} \mathrm{C}\right)\end{array}$ & $\begin{array}{c}\text { Calculation } \\
\text { WBGT }\left({ }^{\circ} \mathrm{C}\right)\end{array}$ & Difference $\left({ }^{\circ} \mathrm{C}\right)$ \\
\hline 1 & Setting & 24,30 & 24,29 & 0,01 \\
2 & Editor & 26,70 & 26,72 & $-0,02$ \\
3 & Computer to Plate & 22,60 & 22,61 & $-0,01$ \\
4 & Content printing & 29,90 & 29,90 & 0 \\
5 & Cover printing & 27,00 & 27,01 & $-0,01$ \\
6 & Key printing & 29,40 & 29,43 & $-0,03$ \\
7 & UV varnish & 29,20 & 29,22 & $-0,02$ \\
8 & Binding & 30,10 & 30,08 & 0,02 \\
9 & Stitching & 29,40 & 29,40 & 0 \\
10 & Packing, Cutting, & 29,10 & 29,10 & 0 \\
\hline
\end{tabular}

\section{Workload}

Assessment of workforce activity at each work station is calculated based on the level of calorie energy demand according to SNI 7269: 2009 so that the level of workload experienced by workers in the production room of CV. Grafika Dua Tujuh can be found. The workload assessment is shown in Table 5.

\section{Table 5.}

Workload According to Energy Needs SNI 7269: 2009

\begin{tabular}{lccccc}
\hline \multirow{2}{*}{ No } & Work & 1 & 2 & 3 & 4 \\
\cline { 3 - 5 } & & Sit & $\begin{array}{c}\text { Stand } \\
\text { up }\end{array}$ & Walk & Hike \\
\hline
\end{tabular}

1 Work by hand 


\begin{tabular}{lcccc} 
Category I $(0,30)$ & 0,6 & 0,9 & 3,3 & 4,1 \\
Category II $(0,70)$ & 1 & 1,3 & 3,7 & 4,5 \\
Category III $(1,10)$ & 1,4 & 1,7 & 4,1 & 4,9 \\
One-handed work & & & & \\
Category I $(0,90)$ & 1,2 & 1,5 & 3,9 & 4,7 \\
Category II $(1,60)$ & 1,9 & 2,2 & 4,6 & 5,4 \\
Category III (2,30) & 2,6 & 2,9 & 5,3 & 6,1 \\
Work using two arms & & & & \\
Category I $(1,25)$ & 1,55 & 1,85 & 4,25 & 5,05 \\
Category II $(2,25)$ & 2,55 & 2,85 & 5,25 & 6,05 \\
$\quad$ Category III $(3,25)$ & 3,55 & 3,85 & 6,25 & 7,05 \\
Work using hand movement & & & & \\
Category I $(3,75)$ & 4,05 & 4,35 & 6,75 & 7,55 \\
Category II $(8,75)$ & 9,05 & 9,35 & 11,75 & 12,55 \\
Category III $(13,75)$ & 14,05 & 14,35 & 16,75 & 17,55 \\
\hline
\end{tabular}

Example of calculation:

Operator Tasks at Content Printing Workstation

a. Folding printing plate for 3 minutes (work done with two arms, standing, category 3-II)

b. Inserting a printing plate into the machine for 5 minutes (work done with hand movements, while standing, category 4-I)

c. Paper rolls job on the machine for 8 minutes (work done with hand movements, while standing, category 4-III)

d. Cleaning the content printing machine for 5 minutes (work done with hand movements, while walking, category 4 -II)

e. Refilling ink for 7 minutes (work done with hand movements, while standing, category 4-I)

f. Setting up the printing machine for 7 minutes (work done with hand movements, while standing, category 4-I)

g. Inspect the printout for 3 minutes (work done with hand movements, while standing, category 4-I)

h. Compiling the printout for 22 minutes (work done with hand movements, while sitting, category 4-I)

Average Workload $=\frac{\left(\mathrm{WL}_{1} \times \mathrm{T}_{1}\right)+\left(\mathrm{WL}_{2} \times \mathrm{T}_{2}\right)+\ldots+\left(\mathrm{WL}_{\mathrm{n}} \times \mathrm{T}_{\mathrm{n}}\right)}{\left(\mathrm{T}_{1}+\mathrm{T}_{2}+\ldots+\mathrm{T}_{3}\right)} \times 60$

Average Workload $=\frac{(2,85 \times 3)+(4,35 \times 5)+(14,35 \times 8)+(11,75 \times 5)+(4,35 \times 7)+(4,35 \times 7)+(4,35 \times 3)+(4,05 \times 22)}{(3+5+8+5+7+7+3+22)}$

Average Workload $=366,9 \mathrm{kcal} / \mathrm{hour}$

The average workload at the binding station with operator assignments is $366.9 \mathrm{kcal} / \mathrm{hour}$ so it is included in the heavy workload category. The total workload calculation is carried out at each production workstation. The results of calculating the total workload based on the level of calorie needs are shown in Table 6.

\section{Table 6.}

Workload Category

\begin{tabular}{ccccc}
\hline No & Workstation & Job & Total Workload & $\begin{array}{l}\text { Workload } \\
\text { Category }\end{array}$ \\
\hline 1 & Setting & Operator & 210,6 & Moderate \\
2 & Editor & Operator & 242,55 & Moderate
\end{tabular}




\begin{tabular}{ccccc}
3 & Computer to Plate & Operator & 286,5 & Moderate \\
4 & Content printing & Helper & 347,7 & Moderate \\
& & Operator & 366,9 & Heavy \\
5 & Cover printing & Helper & 261,4 & Moderate \\
& & Operator & 284,5 & Moderate \\
6 & Key printing & Operator & 298,5 & Moderate \\
7 & UV varnish & Operator & 294,6 & Moderate \\
8 & Binding & Helper & 252 & Moderate \\
& & Operator & 283 & Moderate \\
9 & Stitching & Helper & 252 & Moderate \\
& & Operator & 283 & Moderate \\
10 & Cutting & Operator & 257,4 & Moderate \\
11 & Packing & Operator & 257,6 & Moderate \\
12 & Manual binding & Operator & 254 & Moderate \\
\hline
\end{tabular}

The results of the work climate measurement are then compared with the results of the workload assessment at each workstation in the production room of CV. Grafika Dua Tujuh which can be seen in Table 7.

Table 7.

Measurement Result of Working Climate in the Production Room of CV. Grafika Dua Tujuh

\begin{tabular}{ccc}
\hline No & Workstation & Result \\
\hline 1 & Setting & Meet the standard \\
2 & Editor & Meet the standard \\
3 & Computer to Plate & Meet the standard \\
4 & Content printing & Does not meet the standard \\
5 & Cover printing & Does not meet the standard \\
6 & Key printing & Does not meet the standard \\
7 & UV varnish & Does not meet the standard \\
8 & Binding & Does not meet the standard \\
9 & Stitching & Does not meet the standard \\
10 & Packing, Cutting, Manual binding & Does not meet the standard \\
\hline
\end{tabular}

\section{Improvement of Working Temperature}

The work temperature improvement is carried out only at the content printing workstation because it has a heavy workload category and does not comply with the Permenaker No. 13 of 2011 regarding the WBGT standard. The improvement of working temperature at the content printing workstation is engineering control, namely the installation of a turbine ventilator and exhaust fan. Turbine ventilators and exhaust fans have the same function, which is to suck in hot air and dust and facilitate air circulation so that it will prevent hot air from being trapped in the building.

The content printing workstation is an open space. There is a fan located near the printing machine number 2, and 15 vents measuring $30 \mathrm{~cm} \times 10 \mathrm{~cm}$ located above the right and left walls. Even though there are ventilations in the production room, the workers still feel uncomfortable because the room is hot. After taking measurements, the air temperature near the engine is higher than the air temperature far from the engine, which has a difference of $1.2^{\circ} \mathrm{C}$ to $2^{\circ} \mathrm{C}$. The content printing workstation does not allow enough air circulation because this workstation is adjacent to another building, moreover the content printing workstation has a roof made of zinc. The discussion is carried out by calculating the required number of turbine ventilators and exhaust fans and the appropriate placement. The content printing workstation plan can be seen in Figure 1. 


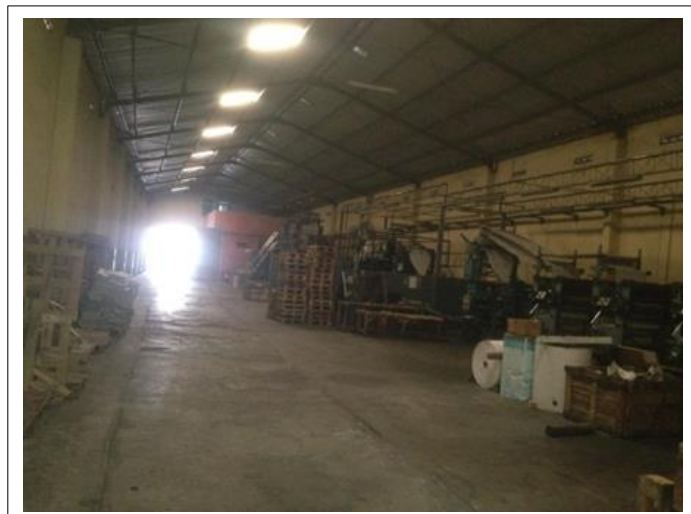

Figure 1. Content Printing Workstation

The dimensions of the content printing workstation are as follows:

Length $=39 \mathrm{~m}$

Width $=11 \mathrm{~m}$

Wall height $=6 \mathrm{~m}$

Roof height form wall $=2 \mathrm{~m}$

Then the volume of the room can be calculated using the following formula:

Vroom $=$ length $\mathrm{x}$ width $\mathrm{x}$ wall height

Vroom $=39 \times 11 \times 6$

Vroom $=2.574 \mathrm{~m}^{3}$

$$
\begin{aligned}
\text { Vroof } & =\frac{1}{2}(\text { length } \times \text { width } \times \text { roof height from wall }) \\
\text { Vroof } & =\frac{1}{2} \times(39 \times 11 \times 2) \\
\text { Vroof } & =429 \mathrm{~m}^{3} \\
\text { Vtotal } & =\text { Vroom }+ \text { Vroof } \\
\text { Vtotal } & =2.574+429 \\
\text { Vtotal } & =3.003 \mathrm{~m}^{3}
\end{aligned}
$$

One of the improvements in thermal conditions at the content printing workstation is engineering control, namely the installation of a turbine ventilator or exhaust fan. If the turbine used is a Cyclon Turbine Ventilator Type L-45 with a suction capacity of $42.39 \mathrm{~m}^{3}$ and a circulation time of 10 minutes, the required number of turbine ventilators is:

Number of turbine $=\frac{\text { Room volume }}{\text { Suction capacity } \mathrm{x} \text { Circulation time }}$

Number of turbine $=\frac{3.003 \mathrm{~m}^{3}}{42,39 \mathrm{~m}^{3} / \min \times 10 \mathrm{~min}}$

Number of turbine $=\frac{3.003 \mathrm{~m}^{3}}{42,39 \mathrm{~m}^{3}}$

Number of turbine $=8$ turbines 
Turbine ventilators can be placed in the center of the roof with a distance of $4.33 \mathrm{~m}$ each. The turbine ventilator design is shown in Figure 2.

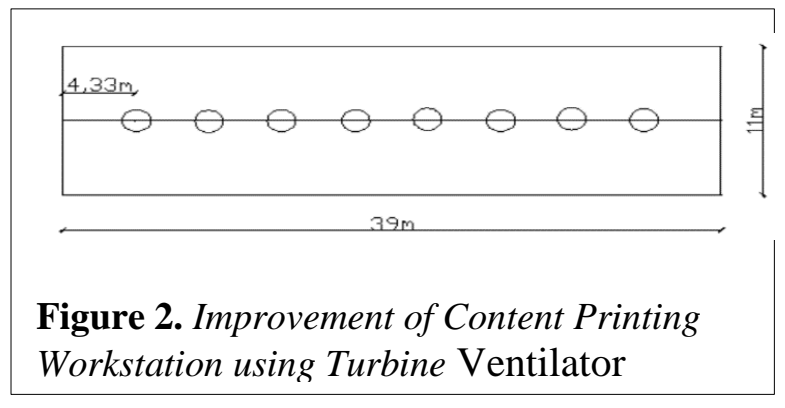

Meanwhile, if the design is carried out using an exhaust fan with a capacity of 5,698.5 $\mathrm{CMH}$, the required number of exhaust fans is:

$\mathrm{CMH}=\mathrm{V} \times \mathrm{ARC}$

Where:

$\mathrm{CMH}=$ Cubic Meter Hour

$\mathrm{ACH}=$ Air Changer per Hour (For the factories, the ACH value is 8 to 10)

$\mathrm{V}=$ Room volume

Calculation

$\mathrm{CMH}=\mathrm{V} \times \mathrm{ARC}$

$\mathrm{CMH}=(39 \times 11 \times 6) \times 10$

$\mathrm{CMH}=25.740 \mathrm{CMH}$

Number of exhaust fan $=\frac{25.740}{5.698,5}$

Number of exhaust fan $=5$ fans

The exhaust fans can be placed on the side of the wall adjacent to the engine at a height of $4.5 \mathrm{~m}$ from under the wall. Exhaust fans design can be seen in Figure 3.

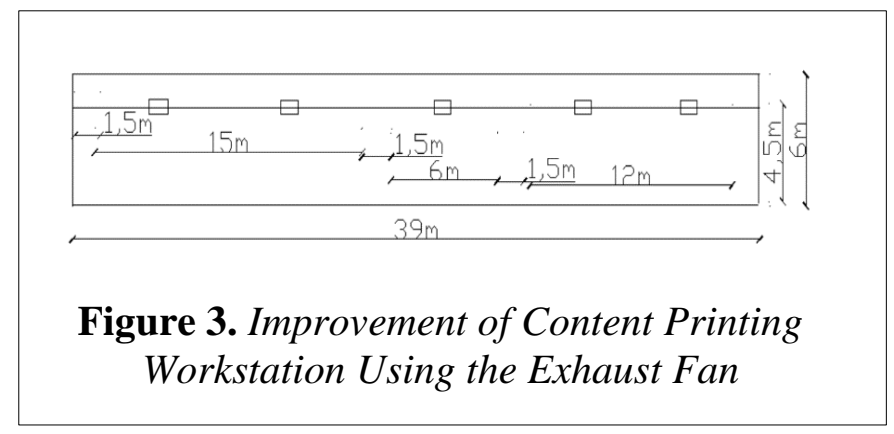

Discomfort conditions at the content printing workstation are due to improper handling of heat exposure. The improvements made are maximizing the use of turbine ventilator or exhaust fan. These improvements will reduce air temperatures and increase wind speed. Thus, workers will feel comfortable so that it will increase company productivity. 


\section{CONCLUSION}

The conclusion of this research is the average working temperature in the production room of CV. Grafika Dua Tujuh, namely setting station is $32.67^{\circ} \mathrm{C}$, editor station is $32.83^{\circ} \mathrm{C}$, CTP station is 29.67 ${ }^{\circ} \mathrm{C}$, content printing station is $33.32{ }^{\circ} \mathrm{C}$, cover printing station is $33.25^{\circ} \mathrm{C}$, key printing station is 33.24 ${ }^{\circ} \mathrm{C}$, UV varnish station is $33.04{ }^{\circ} \mathrm{C}$, binding station is $34.28^{\circ} \mathrm{C}$, stitching station is $133.80^{\circ} \mathrm{C}$, and mixed station is $32.83{ }^{\circ} \mathrm{C}$. The average temperature is above the standard by the Indonesian Ministry of Health, which is $18^{\circ} \mathrm{C}-28^{\circ} \mathrm{C}$. Proposal for improvement made at content printing station that has a heavy workload. Efforts to control heat pressure that are expected to be implemented in CV Grafika Dua Tujuh is by engineering control, namely the addition of turbine ventilators and exhaust fans. To determine the effect of the physical environment on work productivity, it is recommended that the physical environment variables should be added with the variables of noise, lighting, vibration, room color, and work area arrangement.

\section{ACKNOWLEDGEMENT}

This research received no specific grant from any funding agency in the public, commercial, or not-forprofit sectors.

\section{REFERENCES}

Amin, Z., \& Adha, M. (2017). Automatic Temperature and Humidity Control System for Fruit Storage Room. METAL, 1(2), 77-90.

Huda, L., \& Pandiangan, K. (2012). Thermal Assessment Due to Heat Exposure and Work Environment Improvement. Jurnal Teknik Industri, 14(2), 129-136.

Karim, L., Qiram, I., \& Sartika, D. (2018). The Influence of the Number and Angle of Vertical Blade Angle of the Cyclone Turbine Ventilator on the Thermal Comfort of the Room. V-Mac, 3(2), 20-23.

Lien, J., \& Ahmed, N. (2002). Indoor Air Quality Measurement with the Installation of a Rooftop Turbine Ventilator. Journal of Environmental Protection, 3, 1498-1508.

Mamahit, P., Kawatu, P., \& Molanda, N. (2016). The Relationship Between Work Climate and Labor Productivity at PT. Tropica Cocoprima, Lelema, Tumpaan District, Minahasa Selaman Regency. Jurnal Ilmiah Farmasi, 5(1), 335-361.

Meri, M., \& Putra, H. (2016). Control of Work Environment Heat Pressure Based on the ISBB Method. National Conference of Applied Sciences, Engineering, Business, and Information Technology.

Ministry of Health. (2002). Decree of the Minister of Health of the Republic of Indonesia Number 1405 of 2002 Concerning Health Requirements for Office and Industrial Work Environment.

Ministry of Manpower and Transmigration. (2011). Minister of Manpower and Transmigration Regulation No. 13 of 2011 concerning Threshold Value of Physical and Chemical Factors in the Workplace.

Munandar, A. (2001). Industrial and Organizational Psychology. Depok: University of Indonesia.

National Standardization Agency of Indonesia. (2009). Workload Assessment Based on the Level of Calorie Needs according to Energy Expenditure.

Pandiangan, C., Huda, N., \& Rambe, M. (2013). Analysis of Ventilation System Design in Increasing the Thermal Comfort of Workers in the Formulation Room of PT. XYZ. Jurnal Teknik Industri, l(1), 1-6.

Rasyid, M., Surachman, \& Sugiono. (2016). Analysis of Work Station Improvement in Garment Production Process Using Environment Ergonomic Approach. JEMIS, 4(2), 121-129.

Rifa, R., Al-Obaidi, K., \& Rahman, A. (2014). Improving Stack Effect in Hot Humid Building Interiors with Hybrid Turbine Ventilator(s). MATEC Web of Conferences 17, 17, 1-10.

Senata, I.W., Nuridja, I.M., Suwena, K.R.(2014). Pengaruh Lingkungan Kerja Terhadap Produktivitas Kerja Karyawan UD. Kembang Sari Kabupaten Badung Tahun 2012 (The Effect of Work 
Environment on Work Productivity Employees of UD. Kembang Sari Badung Regency in 2012). Jurnal Pendidikan Ekonomi UNDIKSHA, 4(1), 1-10

Wyon, D., \& Wargocki, P. (2005). Room Temperature Effects on Office Work. Creating the Productive Workplace (Second Ed ed.). (Clement-Croome, Ed.) London: Taylor and Francis. 